\title{
Transformational Leadership Model in Islamic Education
}

\author{
Ismail Anshari, Tihalimah \\ Lecturer in Tarbiyah Faculty, UIN Ar-Raniry Banda Aceh \\ ismail.anshari@ar-raniry.ac.id
}

\begin{abstract}
The transformational leadership leads its human resource into its elightment sensitivity, organisational development, collective vision, leadership delegation, and developing organisational culture which is a must in organisational restructure scheme. This leadership model would be able to accelerate the awareness of its followers by promoting productive ideas, a synergical relationship, responsibility, educational concern and collective expcetations. The transformational leadership leaders are those visionary and able to identify changes and transformation into organisations. In addition, they will be able to promote organisational changes and motivate creative and innovative individual employees. Furthermore, they also build strong team work, promote the positive working culture and maintain responsibility.
\end{abstract}

Keywords : Al Quran; transformational leadership; Islamic education; students

\section{Introduction}

The education role in human investment stays at two points. Firstly, the external role of education in the organizations, agencies or even at states level which puts people as trained resource in order to contribute for optimal productivity toward an organization, agencies and states. Secondly, the internal role of education means that education as a need.

The bureaucratic centralistic national education management treats schools as the medium of education arena which rely on bureaucratic decision. It is due that this mechanism plays vital role but sometime it does not deal contextually. It is believed that schools are under the bureaucracy which may not has its independency, flexibility, creativity and innovation in promoting better educational quality.

Recenty, the roles of teachers and parents are very low. In fact, the teachers role is often ignored although teachers are an important stakeholder at schools. It is supposed that the introducing of innovations in order to respond the stagnancy among in the school. In addition, the community role is generally focused on funding support, meanwhile other types of supports such as ideas, morality and facilties are considered low. In fact, schools seem do not have any responsibility to be transparant to the community, and parents. It is believed that both are important elements in supporting education (stakeholders)

Furthermore, the fact that it is an crucial problem of how to improve the quality of education in Indonesia because human resource plays major roles considering from leadership perspective. Qualified human resource across the nation is contributed to national development. Most historical facts have proved that nations education significantly influenced development. The educational advances is realized important, therefore, Indonesian rules the education sector under the Law No. 20 of 2003 on the National Education System mandates the states " national education system should ensure fairness and equality in front of education, therefore, quality improvement and efficiency in education management to challenges changes demands locally and nationally. Indeed, educational reformation should be planned, directed, and sustainable. "

In recent years, there have been major plans and efforts to improve the schools organisational performance. It is due to the need of qualified education in respond to development and technological advances. In current practices, the school system focuses on 
graduates number not the quality of education process. Therefore, it is reasonable that quality of educational processes is very important which is supported by a good schooling system. ${ }^{1}$

To achieve appropriate and qualified organizational performance, it is urgent to have well performed leadership. It is encouraged that leadership should be able to motivate and drive the staff through ispirations and creativity at work. Therefore, transactional and transformational leadership are believed may open the gaps of challenges in imporving schools quality.

In fact, principally a leader has to have managerial skills and understand technical aspects as well. Although a top leader of a large scale organization does not need technical skills, but the skills are usually required by the leader of a small organization. For example, the head of the tehnical leader should have specific techniques in where he can provide applicative advices to his staff..

Furthermore, there are more advantages of skillful leaders in how their ability in communicating with others. By this means the ability to interact, to build relationships and to socialize. As a result, their leadership opportunity is perceived positively by community or all staff. In addition, the influential leader has impacts on community. By this, leaders should have good human relations skills and expertise in building relationships.

\section{Review of Literature}

\subsection{The Definition of Transformational Leadership}

The term, leadership in Islam has several terms namely, khilafah, imamah, imarah, wilayah, sultan, mulk and ri'asah. Each term has a common leadership meaning. But the most frequent used term of government is Khilafah, imamah and imarah. ${ }^{2}$ Therefore, the leadership discourse in Islam is represented by these three terms.

In Arabic, leadership is often translated into al-Riyadah, al-imarah, al-qiyadah, or alzaamah. The terms have similar meaning so that shorthened by muradif. It means that one of the terms may be used to understand the educational leadership. Meanwhile most experts prefer the term qiyadah tarbawiyah.

In Islam, leadership play important roles. It encourages a community to have a leader although it is only a small group. In term of management aspect, Siagian states that leadership is the ability to influence and generate people, nd they would go with orders efficiently and effectively to achieve goals. In thi case, it is limited into management in discussing about leadership. Even though there are several different definitions on leadership, it might be generalized which are applied at organizations.

Leadership is defined as the influence, art or a process to influence people. By this, they are elegantly willing to work enthusiastically to achieve the targetted goals. Indeed, the concept can be expanded which implies not only good works, but also willingnesss in with a feeling of passion and trust are existed. Spirit is believed reflects the excitement, full of sincerity, and intensity in working activities. Trust reflects on experience and technical capabilities. Then, leading describes of how guiding, directing, leading, and the plans. The

\footnotetext{
${ }^{1}$ Meilina Bustari, Kepemimpinan Transformasional kepala Sekolah dalam Meningkatkan Kinerja Organisasi, (Jakarta: Bumi Aksara, 1997), page.176.

${ }^{2}$ Muhammmad Munir Mursi, Al-Tarbiyah al-Islamiyah (Kairo: Dar al-Kutub, 1977), page. 22.
} 
major roles of leaders are to assist the achievement of goals and encourage organisational productivities.

The transformational leadership is formulated from two words, namely leadership (leadership) and (transformational). Leadership itself is explained in the introduction of the article whihc means any actions by a person in coordinating, directing and influencing other people to achieve the goals. In addition, the term transformation is derived from transform, meaning transforming or transforming something into different ways. For example, the transforming of a vision into a reality, or turning something becomes an actual thing.

This leadership type is percieved important to increase awareness of believers to generate productive ideas, mutual relationships, responsibilities, educational awarenesses, and commn visions. The transformational leadership are believed owning futuristic visions to recognize changes and transformations into the organization. It may also share and motivate ideas to employees and a team. The renewal ideas would increase ethical performances and responsibilities of the organization. ${ }^{3}$

The transformational leadership are consisted of two words leadership and transformasional. While, leadership is actions of individuals or groups to coordinate and lead others to achieve certain designed goals. ${ }^{4}$

Furthermore, transformational leadership organizes human resources towards sesitivity awareness, improvement purpose, visions achievement, tasks delegation, and developing positive school organisational cultures.

\subsection{The Transformational Leadership Model}

According to Burns, transformational leadership is the leadership which transforms positive values and at any levels of believers. ${ }^{5}$ Bass states that transformational leadership is where a leader actively motivates the followers to improve commitments, without considering its positive or negative effects. ${ }^{6}$

To conclude both perspectives, so transformational leadership should consider positive or negative moral impacts. Bass and Avolio provide the transformational leadership model in the following picture:

\footnotetext{
${ }^{3}$ Bass, B.M. Leadership and Performance Beyond Expectations, (New York: Free Press, 1985), page. 5.

${ }^{4}$ Sudarwan Danim, Menjadi Komunitas Pembelajar (Kepemimpinan Transformasional dalam Komunitas Organisasi Pembelajaran), (Jakarta: Bumi Aksara, 2003), page. 53.

${ }^{5}$ Burns, R.J, Leadership, (New York: Harper \& Row), 1978, page. 7.

${ }^{6}$ Bass, B.M \& Avolio B.J, The Implication of Transactional and Transformational Leadership: 1994 and beyond. (Journal of Eroupean industrial training, 1994), page. 14, 21-74.
} 


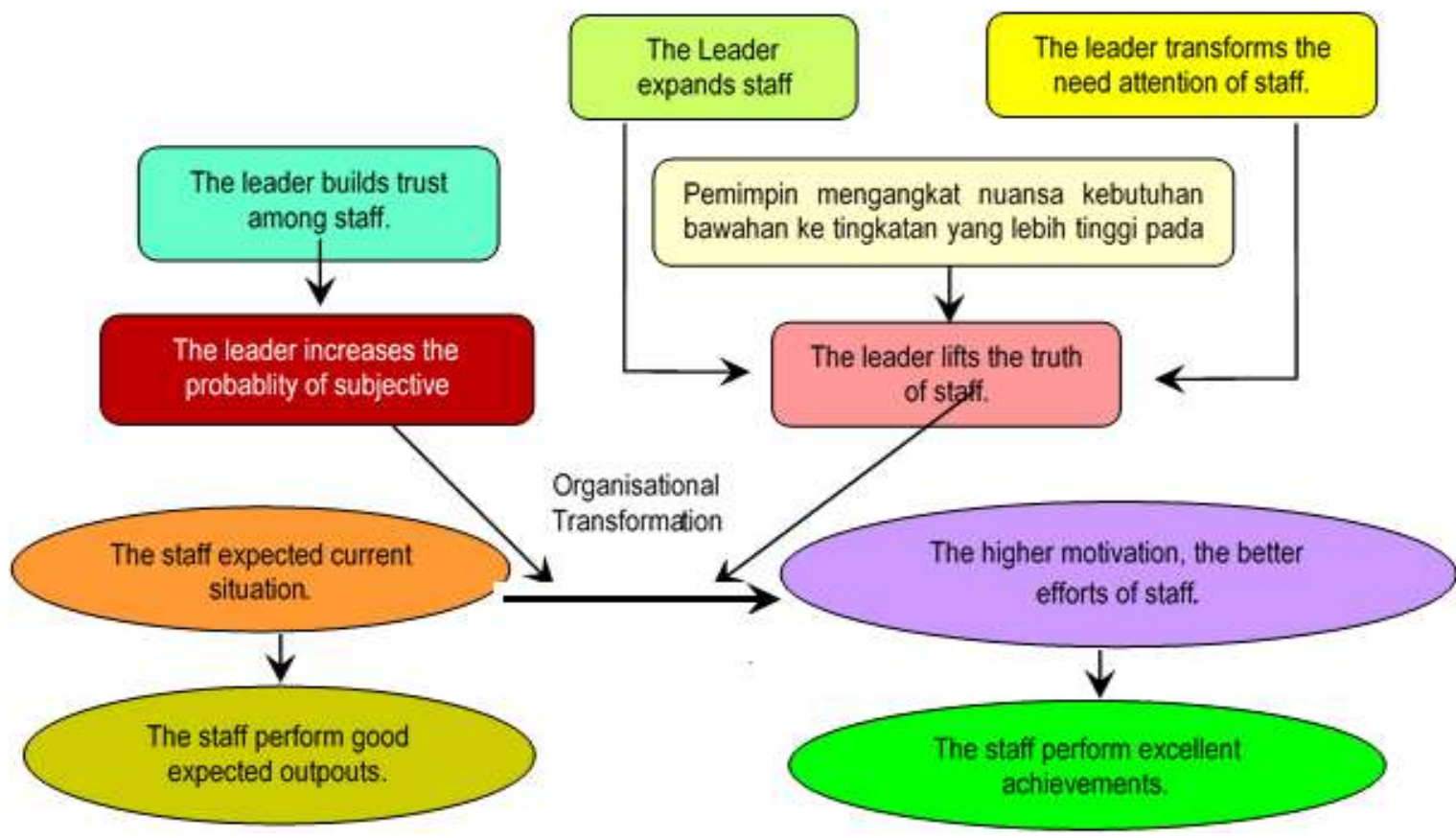

The Picture of Transformational Leadership Model

Source: Bass and Avolio (1994)

Leadership is unrderstood in two definition. First, the power to mobilize and influence people. Then leadership is a process to direct and influence activities related to works of group members. Principally, a leader has capacities to influence people behaviors through his power. In addtion, the power is an authority to lead and influence people under working goals. According to Stoner, having more source of powers owned by a leader would result wider and more effective achievement. Every leader is choosen due to his vision and capacity. Likewise, those who do not have skills and capacities would be difficult to be a leader. Clear visions nd missions would be able to enlight an organisation in the future.

One of the educational leadership models could motivate the establishment of effective educational institution through transformational leadership. This type of leadership improves the leaders capacity on mentality and staff motivation. The leadership concept is offered to all educational levels, so that the people would realize the roles of existing educational institutions to approach changes and innovations.

\subsection{The Typical of Transformational Leadership}

The transformational leadership is an agent of change because regarding the need of an organisational or institutional transformation. The major role is being a innitiator of changes. In addition, the leader has vionary goals on organisation. ${ }^{7}$ Furthermore, the leaders perform actual actions and values. The major element of the transformational leadership is th spirit in achieving the organisation goals. In addition, this typical leaders have diagnostic analysis in understanding challenges and problems in any apsects. ${ }^{8}$ The transformasional leadership

\footnotetext{
${ }^{7}$ Bennis, Warren G. Benne, Kenneth D \& Chin, Robert, Merencanakan Perubahan, (Jakarta: Intermedia, 1990), page. 28.

${ }^{8}$ Sergiovani Thomas J. et. Al, Educational Governance and Administration third edition, (Massacucherts:

Publishing: Publising Group, 1990), page. 21.
} 
emphasizes on the important of value system of its followers on ethical issues, energy mobilization and esource to reform the institution. The transformational leaders would be able to mobilize followers actively through changing processes. Therefore, the transformational leadership has strong personal values in order to bound emotional interaction with staff to achieve the institution goals. Indeed, the leaders loyalty improves ideal belief of the staff to reach long term goals.

\section{The Typical of Transformasional Leaders:}

a. are able to push staff to realize the important of working outputs.

b. are able to support staff to prioritise organisation needs.

c. are able to motivate the higher achievement of staff.

d. are able to facilitate the process of commitment building to achieve organisation goals through staff.

\section{The bahaviors of transformational leaders as follows:}

1) Ideal Influence.

Here, the leaders inspires strongly the emotion and identification on organisation visions.

2) Intelectual Stimulance.

The efforts of leaders to increase awareness on organisational problems throuhg new perspectives.

3) Individual considerations.

Concern, support, and develop staff.

Cunningham and Cordeiro mention three fundamental manings on this transformasional leadership application:

a) Help members and staff to develop and maintain collaboration culture.

b) Promote professional culture

c) Help to fasten educative staff to work effectively on problems solution. The thoughts would be very important to respond lower educational quality and human resource weaknesses in Indonesia.

Meanwhile, the transformation tries to change to better and fair effort, and see any potential ideas.

\subsection{Educational Leadership Approaches}

The common leadership defines particular leadership definition in education sector. There have been many perspectives on leadership issue: "Educational leadership is all activities related to influence personnel through collaborartions and responsibilites to achieve educational goals." In educational context, a leader is defined as a responsible person on changes process at all educational institution levels. Therefore, the leadership function should target on quality of learning process and personnel. It means that the roles of personnel are vey vital in a school. As a result, the school leadership is also important. The educational leader generates the functions of the institution and organizes human resources such as teacher and managerial staff to maximize the work of achieving the goals. According to AsSuwaidan and Basyarahil stated educational leadership is an ability to influence, coordinate, and mobilize people to achieve learning process targets effectively and efficiently.

The management application in education is decided by its leaders. The creative leaders pricipally need to adjust and understand the rules and engagements of an institution or a school. It is expected that the changes could improve learning quality and sustainable. In 
fact, it is often there should be structural transformation of the school which relevant with the orientation of the school itself. The leadership formulates the achievement and successful of the school through various programs. Although the school visions and missions also influence the reaching of the goals. At this point, there should be effective job sharing among the school apparatus.

Formally, the school principal is considered as a leader, while teachers are staff. Therefore, in an organisation, all personnel involve and interact as an organisation system. This typical situation shows teh process of leadership at school scope to support school activites. The educational leadership is a capacity of a leader to mobilize and lead people in educational and learning processes. The main purpose is to achieve the efficiency of educational goals. From various definitions of leadership proposed by experts, mainly focus on the following, (a) there is a person called as a leader, (b) there is a group leaded by a leader, (c) there are goals, (d) there are activities, (e) there are interactions, and (f) there is an authority. It is true that in any group, there would be a trusted leader. The leader should have characters, habits, behaviors, and uniqenesses. In addition, the living style also contributes which could reflect the leadership style of a leader. The term of leadership style is often practiced in an organisation or a formal institution and at a school in particular. The leadership style is often describes the whole understanding of a leader. In fact, it is a way to influence other people through skills and experiences.

sLeadership style is defined as "the way of a leader in handling and influencing staff regarding individual differences." It means that a leader at top position should have capacities to understand any contexts and situations. Therefore, he would be able to adjust his leadership style. Fattah states that any leadership styles focus on two major styles which concern on duty or called Concern for production" and style which focuses on staff of called "Concern for people." Indeed, each organisation or institution may reflect different leadership model. Referring to the contigency leadership perspective, it could be concluded that "being a leader is not only due to personal advances but also influenced by other situational effects." The definition shows that leadership style is a form of most school principals in influencing teachers behaviors in achieving common goals. It is in line with leadership style where "the leader could be able to influence other people." Theoretically, there have been many leadership styles but it is hard to justify the best style. In order to clearly understand the leadership styles, there are three main approaches, namely: behavioral, charateristic, and situational approaches, as follows:

\section{a. Characteristic Approach}

The Characteristic approach explains on characters lead to people success. The approach is related to the assumption on individual perspective which is believed as the heart of leadership. Leadership is seen as something that contains more derived from individuals, especially on individual traits. The followers of the approach tries to understand the characteritic of good or bad qualities leaders.

Leadership is seen as a point that derived from individuals personalities and traits. This approach suggests that certain traits, such as physical strength or friendliness should be major considerations in deciding effective leadership. The not separated personalities, such as intelligence, are thought to be transferred from one situation into another context. The characteristic approach may not be able to answer curiosities and questions in the area of leadership. For example, the optimal combination of personal 
characteristics and decide the successful of a potential leader. It is questionable that characteristic approach can answer critics.

\section{b. Behavioral Approach.}

The behavioral approach does not provide a well defined frame, the experts concern on leaders behaviors. This study focuses and identifies the behavior of leaders in influencing others. The leadership behavior approach sees the effectiveness of leadership styles. Therefore, the goal of the research on leadership was started in 1945 by the Research Center of Ohio State University. This study obtained a picture of two important dimensions of leader behavior called as initiating structure and consideration. The initiating structure describes how a leader limits and structures the roles of subordinates to achieve the goals. Meanwhile consideration describes the degree and relationship characters of a leader with staff where both sides respect each others. By combining two dimensions, initioning structure and consideration konsiderasi could be divided into four leadership styles, as follows:

1) Low consideration, low structure innitiative

2) Low consideration, high structure innitiative

3) Low consideration, low structure innitiative

4) High consideration, high structure innitiative

Furthermore, Tanembuan does not state the most active leadership style, but he describes various styles of leadership are much related to both leaders and staff. Indeed, there are two different ways, otoritary and democratic." Of both models, there are several leadership examples which combine both. This idea is contradicted with saying that an effective leader is much rely on leaders situation and behavior. Three important points that influence leadership styles, namely:

1) Every activity of a leader would reflect his or her leadership and behavioral backgrounds, the trust of employees or staff.

2) The spirit of staff may influence the leader behaviors.

3) The environmental influence may shape the leader as well.

\section{c. Situational Approach}

The situational approach is principally similar with behavioral approach where it concerns on leadership behaviors in certain situations. It is stated that leadership is more on situational functions rather than personal qualities. So that leadership is a reflection of pesronal qualities regarding with interactions with people. In term of behavioral perspective, the studies of leadership have been from various variables and showed behaviors influenced an appropriate leadership style. According to Sutisna "ever variable should be analyzed before the most optimum leadership style may be selected". Therefore, the disccussion on the this topic is specified on the most effective leadership style in certain situation.

In educational organisations, the leader assigns teachers on certain set goals. It is expected the teacher would fulfill the assignments properly and qualified. The application of the certain leardership model aims to influence teachers behaviors, so that the achivements would be maximum. It means that the principal leadership is measured by teachers. As a result, it would support and motivate them in reaching goals. In fulfilling the leadership roles, a leader should not ignore the leadership style 
in the routines of the organisation or the informal institution, it is a major concern of a leader particularly in term of the behaviors. It is due to the purpose of style in influencing people. Leaders would be judged by their subordinates whether they are qualified or not in term of experiences, and skills. As a result, they would give their respect to their leaders.

\section{Discussion}

Regarding the the leadership style, in islamic context, a Khalifa or a leader has strategies to manage and supervise the staff in compiling with their duties. The transformational educational leadership model should be implemented at the educational sector at all leadership levels. This model is believed a good model to deal with the leaders crisis in education sector. The reasons of the urgency of transformational leadership are based on Olga Epitroka ${ }^{9}$ by suggesting six points of why the idea is important for the organisation, as follows:

a. Improve significantly improve the working quality of the organisation;

b. Correlate positively with long term marketing orientation and satisfaction of the costumers;

c. Improve the higher commitment of the organisation members;

d. Increase the employees trust on daily organisation management and behaviors; and,

e. Decrease the stressful pressures on employees and improve their welfare.

The implementation of transformational model in an educational organisation or institution should consider several following points:

a. Referring to religious values in the organisation or institution or even a state;

b. Adjusting with values available in the organisation or institution;

c. Searching cultural values in the organisation or institution; and,

d. Education system is a sub system, therefore, should consider upper level of system such as state system.

Of the the thoughts above, it is percieved that a transformational leader should be able to offer positive organisational changes. The implementation of transformational leadership is expected to have impact on employees not personal or groups.

\section{Conclusion}

Leaders who apply transformational leadership are leaders who have future vision and able to identify environmental changes. In addition, they are able to design organitional changes to transform organisations motivation and inspiration on individuals. They wold be able to provide creative and innovative ideas and build solid team works, which lead to improvements in work and management.

The implementation of transformational leadership education model in educational sector should be applied on school principals, education authority heads, general directors, department heads, etc. The leadership model is believed as a solution in the leadership need in the education sector.

\footnotetext{
${ }^{9}$ Epitropika, Olga, What Is? Transformasional Leadership, Inggris: Institute of Work Psychology University of Sheffield, 2001, page. 1.
} 


\section{References}

Bass, B.M \& Avolio B.J, The Implication of Transactional and Transformational Leadership: 1994 and beyond. Journal of Eroupean industrial training, 1994.

Bass, B.M. Leadership and Performance Beyond Expectations, New York: Free Press, 1985.

Bennis, Warren G. Benne, Kenneth D \& Chin, Robert, Merencanakan Perubahan, Jakarta: Intermedia, 1990.

Burns, R.J, Leadership, New York: Harper \& Row, 1978.

Epitropika, Olga, What Is? Transformasional Leadership, Inggris: Institute of Work Psychology University of Sheffield, 2001.

Indrafachruddin, Mengantar Bagaimana Memimpin Sekolah yang Baik. Jakarta: Ghalia Indonesia, 1995.

Meilina Bustari, Kepemimpinan Transformasional kepala Sekolah dalam Meningkatkan Kinerja Organisasi, Jakarta: Bumi Aksara, 1997.

Muhammmad Munir Mursi, Al- Tarbiyah al-Islamiyah, Kairo: Dar al-Kutub, 1977.

Sergiovani Thomas J. et. Al, Educational Governance and Administration third edition, Massacucherts: Publishing: Publising Group, 1990.

Sudarwan Danim, Menjadi Komunitas Pembelajar Kepemimpinan Transformasional dalam Komunitas Organisasi Pembelajaran, Jakarta: Bumi Aksara, 2003.

Undang-undang Nomor 20 Tahun 2003 Tentang Sistem Pendidikan Nasional UU Sisdiknas. 